\title{
SIGNIFICANT OBSERVATIONS OF TRUMPETER SWANS IN SASKATCHEWAN
}

HAROLD H. BURGESS, 808 South Kansas Ave., Weslaco, TX 78597

Since 1984, Ruth Burgess and I have recorded observations of Trumpeter Swans (Cygnus buccinator) chronologically, by states and provinces. The threatened nature of the Cypress Hills flock and the resettling of the Porcupine Hill area after an absence of a century or more, made Saskatchewan listings more important. It is gratifying that this oncethreatened species continues to increase in numbers and to spread. $H$. Greenwood and A. Young's 1987 "Study on the Restoration of Trumpeter Swan Populations in Saskatchewan" ${ }^{\prime 8}$ challenged us to carefully research their interpretation of history and ornithology, and extend the study of historic Trumpeter Swan occurrences in Saskatchewan.

Early explorers and Hudson's Bay Company post managers differentiated between the two swan species. The larger species, the Trumpeter Swan, arrived earlier in the spring and stayed later in the autumn than the small species, the Whistling or Tundra Swan. Early spring-late autumn criteria allowed Houston and Street ${ }^{11}$ to separate Trumpeter from Whistling Swan data in The Birds of the Saskatchewan River.

The Trumpeter Swan was first described and given its scientific name, Olor buccinator, by $\mathrm{Dr}$. John Richardson in 1832. The type specimen had been 'killed at Hudson's Bay, and [is] now in the H.B. Museum." This was "the most common swan in the interior of the fur-coun- tries. ... its [spring] migrations generally precedes the Geese a few days." The Trumpeter provided "the bulk of the swan-skins imported by the Hudson's Bay Company." 31

The first swans to arrive in spring at Cumberland House, were reported by Indians or HBC employees to the post manager or scribe whose name is given in parentheses ${ }^{11}$ : on 24 March 1774 (Hearne), 31 March 1777 (Cocking), 16 April 1778, 31 March 1779, 11 April 1780, 3 April 1781 (Tomison), 12 April 1782 (Hudson), 10 April 1820 (Lieut. Robert Hood), 20 April, 1840 (Lewis). Although then in a period of lower average temperatures, the swans departed late in the fall, e.g. 13-16 November 1781 (Hudson).

At Lower Hudson House, south of present Shellbrook, swans returned on 6 April 1781 (Longmoor) and 15 April 1782 (Walker). ${ }^{11}$ Between Bolsover House, near present Meadow Lake, and Lac la Biche, Alberta, 8-21 September 1791 Peter Fidler's men ${ }^{14}$ "existed on an insufficient diet of duck, geese, and swans."

In 1858, Thomas Blakiston, ${ }^{11}$ with the Palliser expedition on 30 March 1858, preserved the skin and windpipe of a Trumpeter Swan shot a quarter mile from Fort Carlton. "It measured $601 / 2^{\prime \prime}$ in length, $261 / 2^{\prime \prime}$ in wing, 8' $3^{\prime \prime}$ in extent, bill [culmen] 4 $5 / 8 "$.... It was a male and weighed 23 pounds. Dr. Richardson considers this the more common of the two 


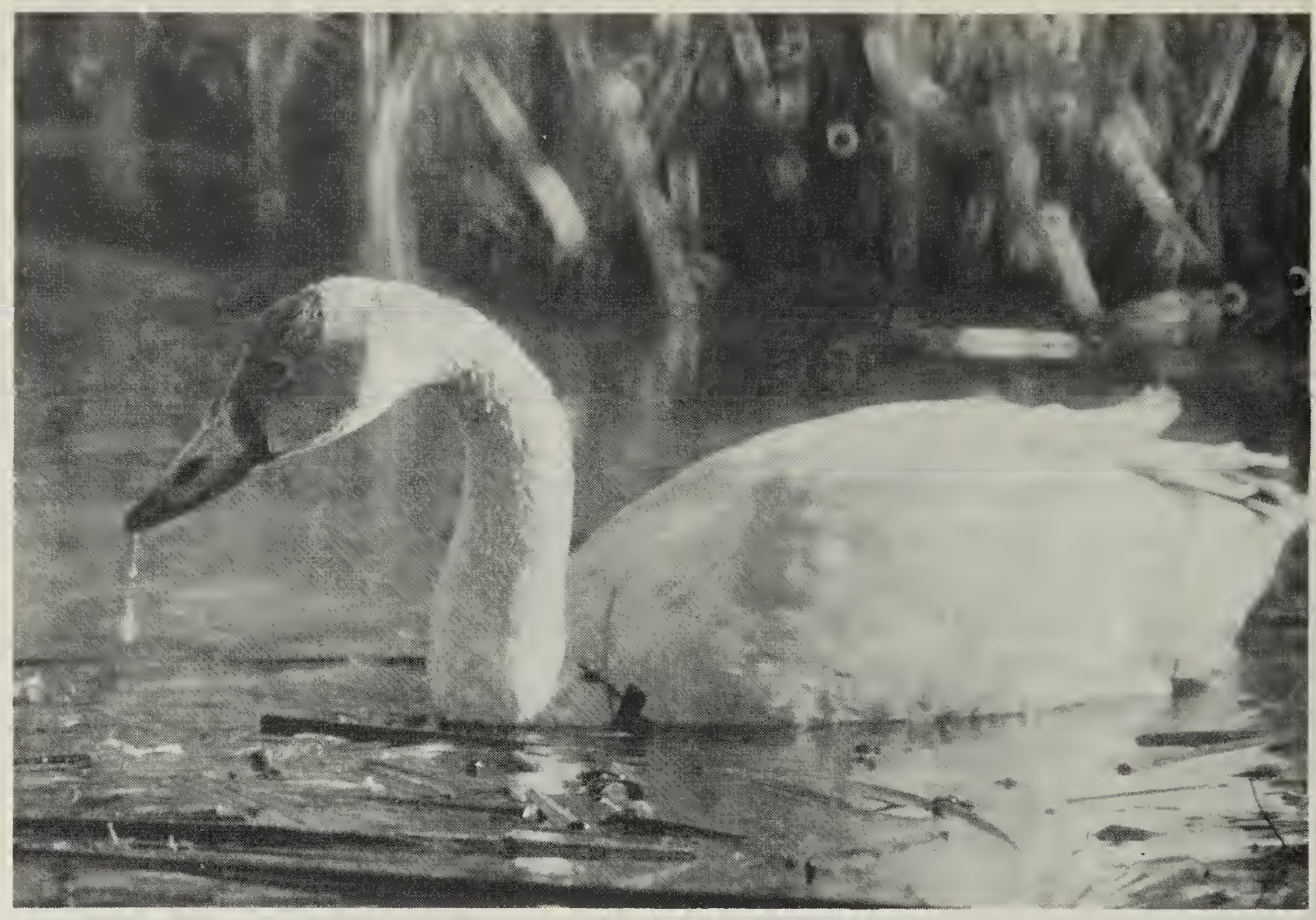

Swans inhabiting the interior and the earlier visitor, with which my observations agree." In mid-September 1862 , north of the Qu'Appelle Valley, between Fort Ellice and Touchwood Hills, Milton and Cheadle noted "occasionally the appearance of ... a flock of white swans gave fresh zest to the sport." 20 These swans were not migrants; cygnets and successful pens (after moult) did not fly until at least 20 September, and migrated much later.

Nero $^{22}$ reviewed early swan sightings in far northern Saskatchewan. Philip Turnor, on 22 August 1791, pitched his tent over the one level place on the island, "an old Swans nest which made us a comfortable bed," on a rocky island on the north shore of Lake Athabasca a few miles east of Fond du Lac. Five days later, near Spring Bay, Turnor saw several swans. David Thompson killed two swans near the south end of Reindeer Lake in mid-July $1796 .^{22}$ For the period 1785 to 1797 , Thompson wrote: "There are two Species of Swans. They lay from seven to nine eggs. When shot, twelve eggs have been counted in them, but nine is the greatest number I have found in a nest, and also of the number they rear., ${ }^{34}$ Nero also reported a modern sighting, from midsummer 1952; A. Stinson reported a bugling swan pair with three cygnets west of Stony Rapids, Saskatchewan. ${ }^{22}$

In neighbouring Manitoba, between 1851 and 1858, two swan eggs from a nest on the banks of a lake near Nonway House were brought to George Barnston. ${ }^{3}$ At Shoal Lake, west of Erinview, Manitoba, Frank Ward, Senior, observed swans with cygnets in 1893-1894. ${ }^{33}$

In Saskatchewan, as with the other nesting areas on the Great Plains, this large bird was extirpated locally by pre-settlement travellers, often before the first settlers arrived. John Macoun saw none in his trips across the prairies in 1872 and 1875, and 
reported that both species of swans "are only seen in migration." ${ }^{18}$ Meagre documentation of breeding persisted into the 1890 s, involving only two nests within what is now Saskatchewan and one twenty miles west in what is now Alberta, would be inadequate were it not for breeding records in contiguous areas, Alberta, Montana, the Dakotas, Minnesota and lowa. ${ }^{1}$ Oliver Davie gave the following second-hand report in 1889 , "On the islands of the fresh water lakes and ponds bordering the north branch of the Saskatchewan River, in British America, a few pairs of the Trumpeter Swan are to be seen throughout the summer." 7 On 7 April 1891 a collector took two sets of five and two eggs from Buffalo Lake. ${ }^{19}$ Evidence that it was not the Buffalo Lake near Stettler, Alberta, but Buffalo Pound Lake, north of Moose Jaw, Saskatchewan, is based on two pieces of information: the same date for Buffalo Lake is given in Raine, who tells us that the eggs were collected by Raine's guide, Mr. Spaulding, who at the time managed a ranch at Rush Lake, Saskatchewan. $^{12}$ There is also oral evidence from Jim Sanderson, a government scout, ${ }^{19}$ who "has lived all his life in Assiniboia and Saskatchewan ... wild swans used to breed on some of the lakes in Northern Assiniboia and Saskatchewan before the Canadian Pacific Railway was built. The last nest he found was during the spring of $1885 \ldots$ at Sounding Lake in Assiniboia, and contained four fresh eggs." [Sounding Lake, $52^{\circ} 08^{\prime}$ North and $110^{\circ} 30^{\prime}$ West, was initially within the postal district of Saskatchewan, immediately north of the postal district of Assiniboia, but the 1905 boundary between the new provinces of Alberta and Saskatchewan was moved east, so that Sounding Lake is now within Alberta, 20 miles west of Saskatchewan.]
A typed note by Fred Bradshaw in the Saskatchewan Museum of Natural History, dated 23 May 1930, found by Dale Hjertaas, told of a swan nest found close to the village of Richard, Saskatchewan, by William V. Geekie. In April 1911 Geekie had found a nest with one very large egg in a patch of short snowberry bushes, $30 \mathrm{~m}$ from the gravelly shore of the marsh, and presumed it belonged to the resident pair of swans. A month earlier he had shot one swan in the same slough; it weighed 28 pounds dressed, clearly a Trumpeter Swan.

In the early part of this century there were fall migration sightings of Trumpeter Swans by a reputable observer, George Lang. Eight Trumpeters at Deep Lake, south of Indian Head, were identified by their calls on 10 November 1921 , and a small group passed down the Qu'Appelle Valley, north of Indian Head, on 26 October 1922. ${ }^{21}$ After a gap of some 60 years, fall sightings are again being reported, such as one seen during the Christmas Bird Count at Squaw Rapids on 24 December $1985,{ }^{13}$ and one at Echo Valley Provincial Park for a full month beginning 1 December $1991 .{ }^{15}$

The first report of breeding on the Alberta side of the Cypress Hills came in 1948, from Twin Lakes at the source of the Battle Creek, three miles west of the Saskatchewan border. The pair there had four young in 1949 and four young in 1950.

First information concerning resident Trumpeter Swans at Cypress Lake, just south of the Cypress Hills, Saskatchewan, came in 1914, when a pair was observed by R.D. Symons. ${ }^{32}$ In the Cypress Hills, in 1953, a pair raised a single young on Adams Lake, and another pair was 
seen at Bottley Lake, a local widening of Adams Creek, 1.5 miles south of Adams Lake; ${ }^{2}$ in 1957, there were 3 adults and 7 young at Bottley Lake; $^{29}$ in 1960, 2 adults and 3 cygnets were present at Adams Lake and another pair, probably with young, on Belanger Creek. ${ }^{16}$ From 1962 through 1965, only one Trumpeter pair was recorded, but by 1966 two pairs were again present. ${ }^{23}$ After four years without reports, a concerted air and group search was made in 1971, finding three breeding pairs within the Cypress Hills Provincial Park and Forest Reserve on two lakes and a beaver pond, with 2, 2 and 4 cygnets, and one non-breeding adult. ${ }^{23}$ In 1972, three pairs had clutches of 6,7 and 5 eggs, and raised 2,2 , and 4 cygnets. ${ }^{27}$ In 1973, two pairs had 6 and 5 eggs on one lake and a beaver pond and raised 3 cygnets each. ${ }^{27}$ In 1974 there were 4 adults and 6 cygnets; $; 6$ in 1975, 4 adults and 1 cygnet; in 1976, 6 adults and 4 cygnets; in 1977, 8 adults and 3 cygnets; in 1979, 4 adults and 6 cygnets. ${ }^{26}$ In 1980, a pair was observed on eggs on 27 May; that year an adult from another pair collided with a power line and its mate disappeared. ${ }^{26}$ From 1983 through 1991, there was only a single pair present, on Coulee Lake; their nest was abandoned in 1986 (the year that I personally observed three nonbreeders farther northeast at Andrew Lake near Piapot), and no nest attempt was made in 1988; 3 cygnets were raised in both 1983 and 1984, 2 cygnets each in 1985, 1987 and 1990 and only one cygnet each in 1989 and 1991. From 1992 through 1995 a single adult was present without a mate. ${ }^{6}$ Neck bands placed by the Canadian Wildlife Service have shown that these birds winter in the overcrowded Yellowstone Park region in Wyoming and adjacent Idaho and Montana. ${ }^{30}$
There have also been summer swan sightings on the eastern boundaries of Saskatchewan. In 1982 swans summered on Swan Lake east of Birch River, Manitoba, approximately 30 miles east of Saskatchewan (Brian Hart, pers. comm. 1982). In July 1987 there were summering swans on Cul de Sac Lake, $53^{\circ} 37^{\prime}$ North, $101^{\circ} 47^{\prime}$ 'West and Murphy Lake, $53^{\circ} 42^{\prime}$ North, $101^{\circ} 47^{\prime}$ West, just west of the Manitoba boundary. ${ }^{8}$ To further confuse the issue, Tundra Swans may on rare occasions summer far south of their normal breeding range. From 1969 through 1981 one productive swan pair at Midnight Lake, ${ }^{28}$ thought from the southern location to be Trumpeters, was determined from egg size and from measurements of a moulting adult, to be Tundra Swans. Two at Tobin Lake, captured during moult on 28 August 1972, also proved to be Tundra Swans. ${ }^{28}$

The exciting news of Trumpeter Swans returning to nest in lakes of the High Tor Hills near Greenwater Lake, Saskatchewan, has been documented by Hooper. ${ }^{9,10}$ Swans observed in summer at Bjork Lake in the mid-1970s and at Marean Lake in 1986 and 1987 were identified retrospectively as probable Trumpeters. ${ }^{9,10}$ In 1989 there were definitive identifications of a pair at Mystery Lake on 28 May, a pair on Marean Lake 27-29 June, ${ }^{9,10}$ and a pair with four young at Raven Lake in July. ${ }^{10}$ In 1990 there was a pair with three young near Pickel Lake in July, perhaps the same pair, and three cygnets that were photographed at Greenwater Lake on 8 May. ${ }^{10}$ On 22 July 1991, Shandruk, Beaulieu and Hooper visited the deserted nest in Greenwater Provincial Park, in shallow cattail habitat $65 \mathrm{~m}$ from shore; an egg contained a fully developed embryo that had failed to hatch. On 
23 July, Len Shandruk captured both moulting adults in a marsh $2 \mathrm{~km}$ from the nest. Yellow neck collars were applied; AC30 on the male and AC31 on the female. These were sighted later that year at Lacreek National Wildlife Refuge, near Martin in southwestern South Dakota on 2931 October. $^{30}$ In 1992 and 1993 male $30 A C$ returned to Greenwater without his mate and in 1993 was with another adult. ${ }^{5}$

In the Porcupine Provincial Forest, from $20 \mathrm{~km}$ east of Greenwater Lake almost to the Manitoba boundary, there were 12 adults and 7 cygnets in $1992,{ }^{4}$ and an aerial survey on 23 August 1993 found 17 adults and 4 cygnets. ${ }^{5}$ That year in August two swans were sighted 40 miles west of Greenwater Park and in September there were four swans east of Carrot River, 60 miles north of Greenwater Provincial Park. ${ }^{5}$

In 1994 there was one pair in Greenwater Park and 20 adults and 10 cygnets in the Porcupine Provincial Forest where in July seven adult Trumpeters were marked with red collars at six sites. All seven, together with yellow-collared 30AC from 1991 (it also was sighted in the two intervening years), appeared at Lacreek Refuge in late October. ${ }^{6}$

In the summer of 1995, there were 20 adults and 5 cygnets in the Porcupine area, and one pair northeast of Fort a la Corne. ${ }^{6}$ During the winter of 1995-96, again one yellowcollared and six red-collared swans staged and/or wintered at Lacreek Refuge (Wayne Runge, pers. comm., 16 March 1996).

We do not know the origin of 12 Trumpeters seen in mid-September 1993 in Prince Albert National Park. ${ }^{5}$
It is disappointing that the "natural" population in the Cypress Hills is no longer productive. However, it is encouraging that the GreenwaterPorcupine flock is increasing. Although this new flock winters in South Dakota, these birds may or may not, in whole or in part, be related to the reintroductions of Trumpeter Swans there.

\section{Acknowle dgements}

I wish to thank Dale Hjertaas and Rhys Beaulieu, Saskatchewan Environment and Resource Management, for their help: Dale for introducing Saskatchewan to us as a Trumpeter Swan study area and for reviewing our reports; Rhys for recent Saskatchewan Trumpeter Swan data. I thank Dan Nieman, Canadian Wildlife Service, for making his Cypress Hills Trumpeter data available. My wife, Ruth Longstaff Burgess, typed the initial drafts and our daughter, Mary Bote, keyboarded this material on her word processor. We thank the Weslaco (Texas) Public Library and particularly Susie Lazono for her persistence in computer searching for and obtaining otherwise inaccessible references. I also wish to thank C. Stuart Houston for his considerable help in the preparation of this article, for adding details to the historical review and for pinpointing obscure geographic locations.

1. BANKO, W. 1960. The Trumpeter Swan. Pub. \#63, N. Am. Fauna, U.S. Fish and Wildlife Service, pp. 8-25.

2. BARD, F. 1953. The Trumpeter Swan. Blue Jay 11(4):26-27.

3. BARNSTON, G. 1860 . Recollections of the swans and geese of Hudson's Bay. Ibis 2:253-259.

4. BEAULIEU, R. 1992. Saskatchewan Trumpeter Swans. Trumpeter Swan Society Newsletter 21(2):7.

5. - 1994. Saskatchewan Trumpeter population increase. Trumpeter Swan Society Newsletter 23(1):13. 
6. - 1996. Recent history of Trumpeter Swans in Saskatchewan. Unpubl. report SERM Wildlife Branch.

7. DAVIE, O. 1889. Nests and eggs of North American birds. Hann and Adair, Columbus, p. 85.

8. GREENWOOD, $H_{\text {., }}$ and A. YOUNG. 1987. Phase I of a study on the restoration of the Trumpeter Swan populations in Saskatchewan, historical range, exploitation, and populations trends 1743-1987. Eikos Ecological Research Associates, Ltd. Prince Albert, Saskatchewan.

9. HOOPER, D.F. 1991. Trumpeter Swans in eastern Saskatchewan. Blue Jay 49:72-74.

10. - 1992. Birds of east-central Saskatchewan. Special publication \#18, Saskatchewan Natural History Society, Regina, pp. 41-43.

11. HOUSTON, C.S., and M.G. STREET. 1959. The birds of the Saskatchewan River, Carlton to Cumberland. Special Publication \#2, Saskatchewan Natural History Society, Regina, Saskatchewan, pp. 42-43.

12. HOUSTON, C. STUART. 1981. An assessment of Walter Raine and his Saskatchewan records. Blue Jay 39:168-181.

13. HOUSTON, M.I. 1986. 44th annual Saskatchewan Christmas bird count, 1985. Blue Jay 44:6-18.

14. JOHNSON, A.M. 1967. Saskatchewan journals and correspondence. Hudson's Bay Record Society, Vol. 26 , London, p. Ixix.

15. KOES, R.F., and P. TAYLOR. 1992. Prairie provinces region. American Birds 46:279-281.

16. LAHRMAN, F. 1961. A second pair of Trumpeter Swans nesting in Saskatchewan. Blue Jay 19:18-19.

17. LISTER, R. 1951. Trumpeter Swans breeding in the Cypress Hills of Alberta. Can. Field-Nat. 65:157-158.

18. MACOUN, J. 1883. Manitoba and the great north-west. Thomas C. Jack, London, p. 364.

19. - 1900. Catalogue of Canadian birds. S.E. Dawson, Queen's Printer, Ottawa, pp. 125-126.
20. MILTON, W.F., and W. B. CHEADLE. 1865. The North-west Passage by land. Cassell, Petter \& Galpin, London, p.55.

21. MITCHELL, H. H. 1924. Catalogue of the birds of Saskatchewan, Can. Field Nat. 38:101-118.

22. NERO, ROBERT W. 1963. Birds of the Lake Athabasca region. Saskatchewan Natural History Society Special Publication \#5, Regina, pp. 41-42.

23. NIEMAN, D.J. 1972. Trumpeter Swans in the Cypress Hills. Blue Jay 30:93-95.

24. - 1976. Population status of Trumpeter Swans breeding in Saskatchewan. Trumpeter Swan Society Newsletter 9:19-20.

25. _ 1978. 1977 status of Saskatchewan Trumpeters. Trumpeter Swan Society Newsletter 15:10.

26. - 1980. Saskatchewan Trumpeters hang on. Trumpeter Swan Society Newsletter 20:6.

27. NIEMAN, D.J., and R.J. ISBISTER. 1974. Population status and management of Trumpeter Swans in Saskatchewan. Blue Jay 32:97-101.

28. NIEMAN, D.J., J.K. GODWIN AND J.R. SMITH. 1983. Whistling Swans breeding in Saskatchewan parkland. Blue Jay 41:92-98.

29. ROY, J.F. 1957. Operation Trumpeter. Blue Jay 15:138-139.

30. SHANDRUK, L., D.F. HOOPER, and R. BEAULIEU. 1992. Trumpeter swans breeding in east-central Saskatchewan. Blue Jay 50:107-108.

31. SWAINSON, W., and J. RICHARDSON. 1832. Fauna Borealiamericana, Vol. 2, the birds. J. Murray, London, p. 464.

32. SYMONS, R.D. 1967. Hours and the birds. University of Toronto Press, Toronto, p. 85.

33. TAVERNER, P.A. 1919. Birds of Shoal Lake, Manitoba. Ottawa FieldNat. 32:137-144.

34. TYRRELL, J.B. $1916 . \quad$ David Thompson's narrative of his explorations in western North America 17841812. The Champlain Society, Toronto, p. 152. 